\title{
Mast cells as regulators of $T$ cell responses
}

\author{
Silvia Bulfone-Paus* and Rajia Bahri
}

Manchester Collaborative Centre for Inflammation Research (MCCIR), Institute of Inflammation and Repair, University of Manchester, Manchester, UK

Mast cells (MCs) are recognized to participate in the regulation of innate and adaptive immune responses. Owing to their strategic location at the host-environment interface, they control tissue homeostasis and are key cells for starting early host defense against intruders. Upon degranulation induced, e.g., by immunoglobulin E (lgE) and allergenmediated engagement of the high-affinity IgE receptor, complement or certain neuropeptide receptors, MCs release a wide variety of preformed and newly synthesized

OPEN ACCESS

Edited by:

Elisabetta Padovan,

University of Basel, Switzerland

Reviewed by:

Carlo Pucillo,

University of Udine, Italy

Shahram Salek-Ardakani,

University of Florida, USA

Eric Espinosa,

University of Toulouse, France

*Correspondence:

Silvia Bulfone-Paus,

Manchester Collaborative Centre for Inflammation Research (MCCIR), Institute of Inflammation and Repair, University of Manchester, Core

Technology Facility, Room 2.18a,

46 Grafton Street, Manchester

M13 9NT, UK

silvia.bulfone-paus@manchester.ac.uk

Specialty section:

This article was submitted to Immunological Memory, a section of the journal Frontiers in Immunology

Received: 31 May 2015

Accepted: 19 July 2015

Published: 07 August 2015

Citation:

Bulfone-Paus S and Bahri R (2015)

Mast cells as regulators of $T$ cell

responses.

Front. Immunol. 6:394.

doi: 10.3389/fimmu.2015.00394 products including proteases, lipid mediators, and many cytokines, chemokines, and growth factors. Interestingly, increasing evidence suggests a regulatory role for MCs in inflammatory diseases via the regulation of $T$ cell activities. Furthermore, rather than only serving as effector cells, MCs are now recognized to induce T cell activation, recruitment, proliferation, and cytokine secretion in an antigen-dependent manner and to impact on regulatory T cells. This review synthesizes recent developments in MC-T cell interactions, discusses their biological and clinical relevance, and explores recent controversies in this field of MC research.

Keywords: mast cells, CD4 T cell, CD8 T cell, Treg cells, adaptive immunity

\section{Introduction}

Mast cells (MCs) are among the most malleable and rapidly responding cells of the immune system. Within seconds of activation, they release a multitude of preformed biologically active products, followed by marked changes in cytoplasmic composition and volume that enable reconstitution of their morphology and cell content within hours $(1,2)$. Counterintuitively, this cell-regenerative phase coincides with a striking wave of mediator synthesis and secretion. Therefore, tissue-resident MCs have the potential to strongly shape their tissue microenvironment and direct cell-cell interactions and immune cell responses even while running through a reconstitution phase, during which they are relatively "refractory" to external stimuli.

Derived from either hematopoietic precursors or local, tissue-resident progenitors, mature MCs represent a heterogeneous collective of long lived, granulated cells located in essentially all tissues, which increase in number upon proliferation or increased recruitment, survival, and/or maturation of MC progenitors (1-3). They are particularly abundant at barrier sites, such as the skin, lung, and gut, and play an important role in defense against, and clearance of various pathogens $(4,5)$.

While the involvement of MCs in allergic/inflammatory reactions triggered by the crosslinking of FceRI-bound immunoglobulin E (IgE) by antigen has been characterized in detail (6), the extent of MC function in autoimmune diseases is less well understood $(7,8)$. Upon activation, MCs release a plethora of mediators, including growth factors, cytokines, and chemokines (e.g., IL-1, IL-6, IL-8, IL-10, TNF $\alpha$, VEGF, TGF $\beta$, CCL2-4) as well as pro-inflammatory lipid mediators, such as prostaglandins and leukotrienes. However, MCs are mostly known for the ability to degranulate and 
very rapidly release preformed mediators from cytoplasmic granules, such as vasoactive amines (histamine and serotonin), proteoglycans (e.g., heparin), proteases (above all tryptases and chymases), and some pre-stored cytokines (e.g., TNF $\alpha)(1,2,9)$.

As players in innate immunity MCs have the capacity to initiate and amplify immune responses. Several lines of evidence have demonstrated that MCs participate in the sensitization phase of acquired immune responses via the secretion of mediators, which sustain dendritic cell (DC) maturation, function, and recruitment to the tissue or their migration to local draining lymph nodes (10). However, MCs also exert important effector function since MCs and $\mathrm{T}$ cells of different origin and subsets establish tight cell-cell interactions and modulate their respective effector functions in a bidirectional manner; this has been shown in a variety of models (11-13). Interestingly, MCs can even present antigen to T cells in a MHC class I- or class II-restricted mechanism $(11,13,14)$.

This review focuses on MC-mediated regulation of $\mathrm{T}$ cell responses (Figure 1) since this activity not only shows MCs to be an important element of acquired immunity but also to play a cardinal role in shaping, controlling, sustaining, or arresting inflammatory responses at host-environment interfaces and, thus, of major clinical relevance.

\section{MCs as Regulators of CD4 ${ }^{+} \mathbf{T}$ Cell Effector Functions}

Historically, MCs have been associated with the regulation of Th2 immune responses, and as such their modulatory activities on $\mathrm{CD}^{+}{ }^{+} \mathrm{T}$ cells have been amply documented in many different models (Figure 1A).

In 1993, the Mecheri group reported that murine bone marrowderived mast cells (BMMCs) displayed antigen-presenting cell (APC) functions (15), with these findings later extended to MCs of rat and human origin (16-18). Efficient BMMC antigen presentation to $\mathrm{CD}^{+}{ }^{+} \mathrm{T}$ cells was shown to require expression of the costimulatory molecules CD80 and CD86, which are induced by IL-4 and granulocyte/macrophage-colony-stimulating factor (GM-CSF). Interestingly, in their studies, interferon (IFN) $\gamma$ completely abrogated this phenomenon $(19,20)$; this IFN $\gamma$ effect could
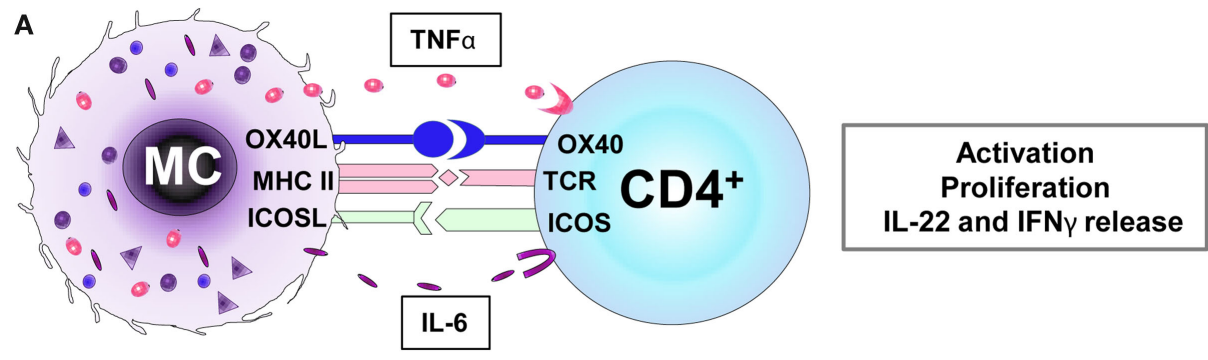

B
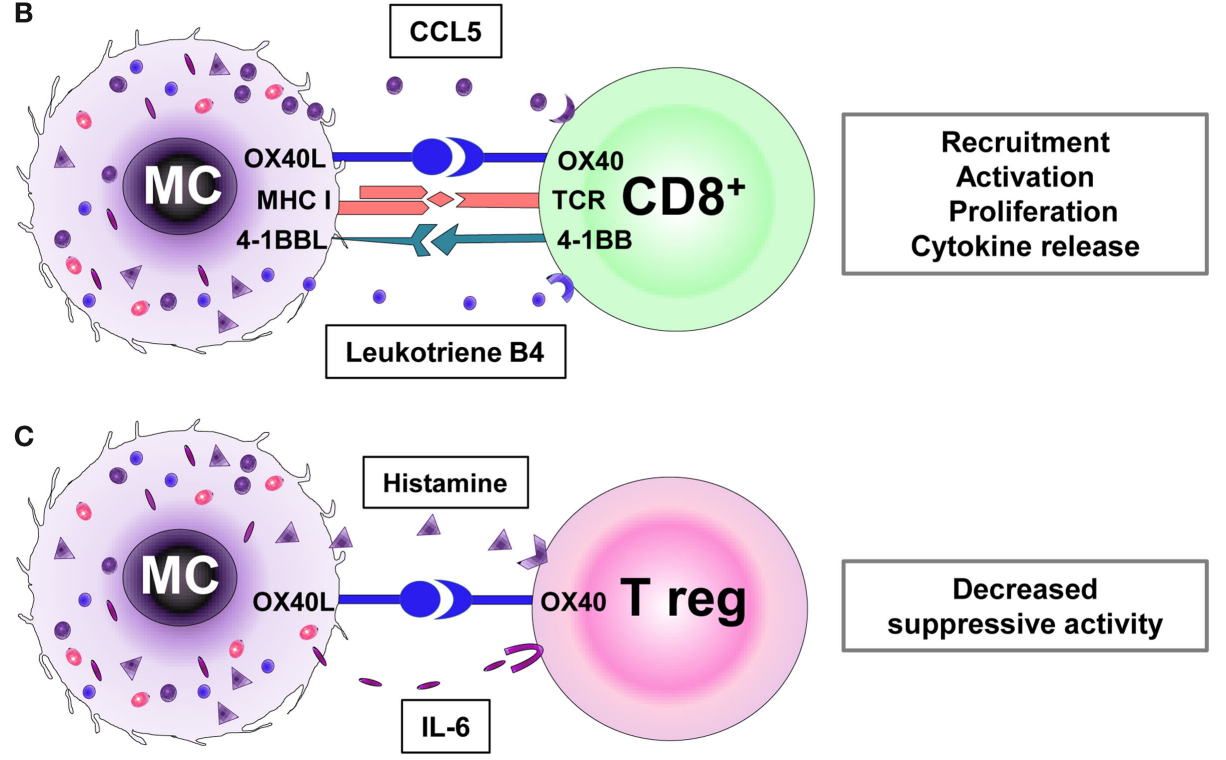

FIGURE 1 | Receptors and mediators involved in the interaction between mast cells (MCs) with $\mathrm{CD}^{+}{ }^{+}(\mathrm{A}), \mathrm{CD}^{+}(\mathrm{B})$, and regulatory $\mathrm{T}$ cells (Tregs) (C). (A) MCs promote the activation, proliferation, and cytokine secretion (e.g., IL-22, IFN $\gamma$ ) of CD4 ${ }^{+}$T cells via MHC II and OX4OL cell-cell interactions and TNF $\alpha$ secretion. (B) MCs induce $\mathrm{CD}^{+} \mathrm{T}$ cell recruitment via the release of chemokines (e.g., CCL5) and leukotriene B4. Furthermore, MC-mediated $\mathrm{CD}^{+}{ }^{+} \mathrm{T}$ cell activation requires MHC I/TCR, OX40L/OX40, and 4-1BBL/4-1BB receptors interaction. (C) The OX40/OX4OL-directed interaction between Treg and MCs and the histamine and IL-6 production by the latter inhibit the suppressive Treg activity. 
be counteracted by FcعRI-mediated antigen endocytosis (21). In contrast to the above study, IFN $\gamma$-primed mouse MCs in their antigen-mediated interaction with $\mathrm{CD} 4^{+} \mathrm{T}$ cells were shown to develop a functional immunological synapse (22).

More recently, Gaudenzio and colleagues (23) have defined MCs as "tissue-localized" APCs, which (in inflamed human psoriatic skin) are primed by locally produced IFN $\gamma$ to present antigen to experienced and recruited CD $4^{+} \mathrm{T}$ cells. IFN $\gamma$-primed human MCs establish synaptic contacts with effector/memory CD4 ${ }^{+} \mathrm{T}$ cells, thus inducing Th22 and IL- $22^{+}$IFN $\gamma^{+}$Th cell subsets via the release of IL- 6 and TNF $\alpha$. Interestingly, in inflammatory conditions in which both MCs and T cells are enriched, as seen in psoriatic skin, the majority of IL- $22^{+}$and IFN $\gamma^{+} \mathrm{CD} 4^{+} \mathrm{T}$ cells are in close contact with MCs and the latter act as amplifiers of inflammation (23).

Since IL- 6 and TNF $\alpha$ are mediators commonly released by activated MCs upon a wide range of stimuli, it remains unclear whether the IFN $\gamma$-induced MC search for immune partners is broad or restricted to a specific cell type or T cell subset; and how this encounter is spatially and temporally controlled. Furthermore, whether this cognate interaction leads to bidirectional effector functions, which might shape long-term MC activities is yet to be defined.

The antigen presentation activity of murine MCs and the MC-dependent modulation of effector $\mathrm{T}$ cell functions correlates with the induced expression of MHC class II molecules $(14,24)$ together with the up-regulation of a wide variety of costimulatory molecules, including members of the B7 family (ICOS ligand, PDL1, and PD-L2) and the TNF/TNFR families (OX40L, CD153, Fas, and $4-1 \mathrm{BB})(25)$.

In conjunction with the secretion of TNF $\alpha$, the up-regulation of the costimulatory molecule OX40L, in particular, has been demonstrated to be essential for the MC-CD4 ${ }^{+} \mathrm{T}$ cell crosstalk and modulation of effector $\mathrm{T}$ cell function (25). OX40L expression was reported to be induced by exposure of mouse MCs to stimuli, such as toll-like receptor (TLR) agonists and FceRI engagement (24). Furthermore, Notch signaling was shown to upregulate MHC class II and OX40L expression on mouse MCs thus promoting the proliferation $\mathrm{CD}_{4}{ }^{+} \mathrm{T}$ cells and their differentiation into $\mathrm{T}$ helper 2 cells producing IL-4, IL-5, IL-10, and IL-13 (26).

Interestingly, treatment of human MCs with type I IFNs had the opposite effect of down-regulating both TNF $\alpha$ and OX40L expression while inducing IL-10 and TGF $\beta$ production with the consequence of restraining $\mathrm{CD}^{+}{ }^{+} \mathrm{T}$ cell effector activities (27). This latter report underlies the key role of the inflammatory microenvironment in tightly controlling the outcome of MC-T cell interactions, and also suggests that the antigen presentation ability of MCs is possibly not intrinsic to this cell type but varies in response to time and location.

Gong and colleagues have proposed that the antigen-presenting property is restricted to an $\mathrm{FcERI}^{\mathrm{hi}}, \mathrm{MHC} \mathrm{II}^{+}$, and c-kit ${ }^{+}$mouse MC subset (28). However, considering the plasticity of MCs, one could interpret the FcERI ${ }^{\text {hi }}$ and MHC $\mathrm{II}^{+}$expression on MCs rather as a transitory "activation" state born of environmental (allergen) or inflammatory pressure rather than as a bona fide subset of MCs.

In vitro as well as in vivo MCs are a heterogeneous cell population, and their MHC class II expression is variable and inducible. However, MHC class II molecules are not confined to a "professional" MHC class II compartment as it is found in professional APCs, but are stored in mature and immature forms in both lysosomal and secretory granules of MCs [Ref. (29); reviewed in Ref. (11)]. Furthermore, it has been reported that MC-mediated $\mathrm{T}$ cell activation is mediated via exosome release (30). It is therefore tempting to speculate that antigen presentation in MCs may be the result of both direct cognate cell-cell interactions between MCs and T cells and MC-secreted MHC class II and costimulatory molecule-loaded exosomes acting upon T cells.

\section{MCs as Modulators of $\mathrm{CD}^{+} \mathrm{T}$ Cell Responses}

Recent evidence has suggested a protective role for MCs in antiviral immune responses (31-35). This is based on the observation that MCs are equipped with a full repertoire of pattern recognition receptors, including TLRs (36), which allow MCs to sense and respond to most microbial components, including viruses.

Upon TLR engagement, mouse MCs are activated to secrete chemokines, of which notably CCL5 can recruit effector $\mathrm{CD} 8^{+}$ $\mathrm{T}$ cells (37). Reovirus-infected human MCs have been shown, through release of chemokines including CCL3, CCL4, and CCL5, to selectively recruit cytotoxic effector cells, thus suggesting their ability to enhance viral immunity (31).

Furthermore, in a model of murine cytomegalovirus (CMV) infection, activated MCs have been described to recruit $\mathrm{CD}{ }^{+}$ $\mathrm{T}$ cells to the lungs via CCL5 release and thus contribute to a reduction in the viral load and the clearance of infection (34). MC activation upon CMV infection is characterized by an immediate TLR3/TRIF signaling-dependent phase and a delayed TLR3/TRIF-independent pathway phase (38). In allergy models, the MC-mediated recruitment of effector, but not central memory, $\mathrm{CD}^{+} \mathrm{T}$ cells to sites of inflammation was shown to be dependent on the production of MC leukotriene B4 (39).

However, the interactions between MCs and $\mathrm{CD}^{+}{ }^{+} \mathrm{T}$ cells go far beyond that of chemokine-induced recruitment (Figure 1B). MCs have been reported to be capable of antigen presentation via MHC class I molecules to $\mathrm{T}$ cells following phagocytosis and processing of bacterial antigens from live bacteria (40). Furthermore, physical MC/CD8 ${ }^{+}$T-cell contacts have been demonstrated in healthy human skin. In lesional skin from alopecia areata (AA) patients, MCs display an activated phenotype prominently expressing MHC class I and the costimulatory molecules OX40L and 4-1BBL. Furthermore, abnormal MC numbers, effector functions, and increased interactions with $\mathrm{CD}^{+} \mathrm{T}$ cells were observed in the grafted $\mathrm{C} 3 \mathrm{H} / \mathrm{HeJ}$ mouse model of AA and in a recently developed humanized mouse model for AA (41). Here, in a pathological inflammatory environment, activated MCs may contribute to the collapse of hair follicle immune privilege by initiating/sustaining $\mathrm{CD}^{+}{ }^{+} \mathrm{T}$ cell effector functions, thus promoting the disease (41).

Importantly, $\mathrm{MC}$ initiated antigen-dependent and $\mathrm{MHC}$ class I-mediated cross-presentation to $\mathrm{CD}^{+} \mathrm{T}$ cells has been shown to regulate $\mathrm{CD}^{+} \mathrm{T}$ cell effector functions including proliferation, cytokine secretion, and cytotoxic activity in vitro; 
this was supported by complementary in vivo studies in which antigen-specific $\mathrm{CD}^{+} \mathrm{T}$ cell numbers were reduced in MC-deficient mice, using the experimental autoimmune encephalomyelitis (EAE) model (42). These studies support previously published evidence that MC-deficient mice not only display defective $\mathrm{CD}^{+}{ }^{+}$but also $\mathrm{CD} 8^{+}{ }^{+}$T cell numbers in EAE (43) as well as in Leishmania major infection (44).

A specific priming of $\mathrm{CD}^{+}$effector T cells in the tissue at the site of inflammation, delivered by resident immune cells, such as MCs, may also be a relevant strategy not only to, initially, promote protective inflammation but also to control and limit excessive and/or chronic cytotoxic activity. However, very little evidence has been published to date on $\mathrm{CD}^{+} \mathrm{T}$ cell/MC interactions. Therefore, closing this important gap in our understanding of MCs functions in health and disease should be a prime future research focus.

\section{MCs as Suppressors of T Cell Effector Functions}

Mast cells are also able to suppress $\mathrm{T}$ cell effector functions, namely, by their interaction with regulatory $\mathrm{T}$ cells (Treg) (Figure 1C). Adoptive transfer of Tregs in a mouse model of sepsis correlated with increased MC numbers (45). Furthermore, MCs contribute to the induction of tolerance to alloantigens being recruited to skin allografts in response to IL-9 secreted by Tregs $(46,47)$.

In line with the previously reported finding that high-FceRI expression correlates with efficient antigen-presenting abilities in MCs $(24,28)$, Treg cells down-regulate FceRI expression in MCs (48). Mouse MCs have been shown to secrete histamine and IL-6 and to use the OX40/OX40L signaling pathway to inhibit Treg functions and to thus promote optimal activation of effector $\mathrm{CD}^{+}{ }^{+}$and $\mathrm{CD}^{+}{ }^{+} \mathrm{T}$ cells (49-52).

However, it remains unclear which conditions promote the suppression of MC functions by Tregs versus the inhibition of Tregs by MCs. Moreover, it is conceivable that, under some conditions, MC activation may overcome Treg-mediated immunosuppression, promote the development of effective antitumor immunity, and boost the immune response in the tissue, while a different signaling environment may contribute to allograft tolerance in transplantation. Only a better definition of the relevant molecular check points will clarify the mechanisms that underlie these opposite functional outcomes and will identify promising targets for therapeutic interventions.

\section{Controversies in the Field}

However, it should be acknowledged that the regulatory impact of MCs on T cell functions is still a controversially debated field. Namely, studies utilizing various MC-deficient mouse models have claimed that MCs are non-essential for the regulation of either $\mathrm{CD}^{+}{ }^{+}$or $\mathrm{CD}^{+}{ }^{+} \mathrm{T}$ cell immune responses $(53,54)$. Yet, this does not necessarily exclude $\mathrm{T}$ cell-regulatory $\mathrm{MC}$ activities under physiological conditions.

Mast cell function has been classically studied using the MCdeficient $\mathrm{C} 57 \mathrm{BL} / 6-\mathrm{Kit}^{\mathrm{W}-\mathrm{sh} / \mathrm{W}-\mathrm{sh}}$ or $\mathrm{Kit}^{\mathrm{W} / \mathrm{W}-\mathrm{V}}$ mice, whose $\mathrm{MC}$ deficiencies arise through loss of function mutations affecting Kit. However, these mice are limited in their usefulness by their perturbed immune cell composition, as such a number of new "Kit-independent" MC-deficient strains have been generated (53, $55,56)$. These mice have the great advantage of deleting the MC population without apparently affecting other immune populations, with the exception of basophils (strain dependent), and have called into question findings originally obtained using Kitdependent MC-deficient mice.

Owing to the use of multiple mouse strains and diseases models, the role of MCs in autoimmune diseases has been very controversial, with some authors tending to conclude that MCs are generally dispensable in autoimmunity (53). However, very recently, Schubert and colleagues investigated in more detail the function of MCs in arthritis using different strains of MC-deficient mice and in models, either based on autoreactive antibody transfer or effector T cells (57). Interestingly, these authors found MCs to be critically relevant in the $\mathrm{T}$ cell-dependent mouse model of rheumatoid arthritis [collagen-induced arthritis (CIA)], while being dispensable in the $\mathrm{T}$ cell-independent antibody-induced arthritis model. In the CIA model, absence of MCs resulted in dramatic loss of $\mathrm{T}$ cell expansion upon immunization and concomitant reduction in $\mathrm{T}$ cell cytokine responses (57). These recent findings underscore the critical role of MCs in T cell-dependent autoimmunity.

However, in a $\mathrm{T}$ cell-dependent spontaneous diabetes model, using non-obese diabetic (NOD) mice, MCs failed to impact on $\mathrm{CD}^{+}{ }^{+}$and $\mathrm{CD}^{+} \mathrm{T}$ cell numbers measured at the onset of the disease (54). However, this study left it unclear whether at later time points during disease progression, i.e., when the phenotype divergence between $\mathrm{MC}$ deficient and wild-type mice may be greatest, or during spontaneous disease resolution, the absence or presence of MCs would have impacted upon T cell responses and clinical outcome.

Possibly, the most contentious issue has been the role of MCs in multiple sclerosis (MS), particularly in the T cell-dependent surrogate mouse model of EAE, with some studies arguing an important role for MCs $(58,59)$, while another one claims that they are dispensable (53). This controversial discussion has been very important and productive in the sense that it has brought to light the limitations in the use of each of the presently available MC-deficient mouse strains, and has underscored the urgent need for standardized disease-induction protocols to improve data reproducibility. Furthermore, these discrepancies have served to acutely remind us of the constitutive difficulties one faces in translating murine data to the human condition.

\section{Conclusion and Perspectives}

In this review, we have highlighted interactions between MCs and $\mathrm{T}$ cells, which regulate adaptive immune responses and have delineated that the antigen-presenting activity of tissueresident immune cells, such as MCs, is fundamental to the maintenance of productive and protective inflammation. MCs may also actively participate in the fundamental processes, which minimize immune-mediated bystander damage to healthy tissues. 
We have also reviewed the evidence that MC can modulate Treg activities. However, the mechanisms and dynamics that interrupt MC-mediated antigen presentation, down-regulate the MCinduced amplification of $\mathrm{T}$ cell-dependent immune response, and restore local Treg cell homeostasis, all remain to be dissected by future research.

This review has closed with discussing contradictory results and the ensuing controversial debate on the role of MC in experimental autoimmune disease. It is important to keep in mind that the conflicting findings were generated using different $\mathrm{MC}$ deficient mouse strains. This raises the pertinent question whether models, which rely on the deletion of an entire cell population, such as MCs, which are notoriously heterogeneous, highly plastic and adaptable in nature, and excel in their capacity to rapidly shift the spectrum of mediators released and surface markers expressed in distinct signaling environments (e.g., homeostatic versus inflammatory settings), are not overly simplistic. Can such

\section{References}

1. Galli SJ, Grimbaldeston M, Tsai M. Immunomodulatory mast cells: negative, as well as positive, regulators of immunity. Nat Rev Immunol (2008) 8:478-86. doi:10.1038/nri2327

2. Gurish MF, Austen KF. Developmental origin and functional specialization of mast cell subsets. Immunity (2012) 37:25-33. doi:10.1016/j.immuni.2012. 07.003

3. Sugawara K, Bíró T, Tsuruta D, Tóth BI, Kromminga A, Zákány N, et al. Endocannabinoids limit excessive mast cell maturation and activation in human skin. J Allergy Clin Immunol (2012) 129:726-38. doi:10.1016/j.jaci.2011. 11.009

4. Janssens AS, Heide R, den Hollander JC, Mulder PG, Tank B, Oranje AP. Mast cell distribution in normal adult skin. J Clin Pathol (2005) 58:285-9. doi:10.1136/jcp.2004.017210

5. Abraham SN, St John AL. Mast cell-orchestrated immunity to pathogens. Nat Rev Immunol (2010) 10:440-52. doi:10.1038/nri2782

6. Galli SJ, Tsai M. IgE and mast cells in allergic disease. Nat Med (2012) 18:693-704. doi:10.1038/nm.2755

7. Walker ME, Hatfield JK, Brown MA. New insights into the role of mast cells in autoimmunity: evidence for a common mechanism of action? Biochim Biophys Acta (2012) 1822:57-65. doi:10.1016/j.bbadis.2011.02.009

8. Rodewald HR, Feyerabend TB. Widespread immunological functions of mast cells: fact or fiction? Immunity (2012) 37:13-24. doi:10.1016/j.immuni.2012. 07.007

9. Jobbings CE, Sandig H, Whittingham-Dowd JK, Roberts IS, Bulfone-Paus S. Listeria monocytogenes alters mast cell phenotype, mediator and osteopontin secretion in a listeriolysin-dependent manner. PLoS One (2013) 8:e57102. doi: 10.1371/journal.pone.0057102

10. McLachlan JB, Shelburne CP, Hart JP, Pizzo SV, Goyal R, Brooking-Dixon R, et al. Mast cell activators: a new class of highly effective vaccine adjuvants. Nat Med (2008) 14:536-41. doi:10.1038/nm1757

11. Valitutti S, Espinosa E. Cognate interactions between mast cells and helper T lymphocytes. Self Nonself (2010) 1:114-22. doi:10.4161/self.1.2.11795

12. Gri G, Frossi B, D'Inca F, Danelli L, Betto E, Mion F, et al. Mast cell: an emerging partner in immune interaction. Front Immunol (2012) 3:120. doi:10. 3389/fimmu.2012.00120

13. Mekori YA, Hershko AY, Frossi B, Mion F, Pucillo CE. Integrating innate and adaptive immune cells: mast cells as crossroads between regulatory and effector B and T cells. Eur J Pharmacol (2015). doi:10.1016/j.ejphar.2015. 03.087

14. Kambayashi T, Laufer TM. Atypical MHC class II-expressing antigenpresenting cells: can anything replace a dendritic cell? Nat Rev Immunol (2014) 14:719-30. doi:10.1038/nri3754

15. Frandji P, Oskéritzian C, Cacaraci F, Lapeyre J, Peronet R, David B, et al. Antigen-dependent stimulation by bone marrow-derived mast cells of $\mathrm{MHC}$ class II-restricted T cell hybridoma. J Immunol (1993) 151:6318-28. models possibly reflect the (very transitory) dynamics of MC biology in vivo? Therefore, the ultimate research tool for definitively clarifying the contribution of MCs to the regulation of T cell functions under physiological and pathological conditions, which fully takes into account the dynamism and heterogeneity of MCs, may still have to be developed.

\section{Author Contributions}

$\mathrm{SP}$ and RB drafted and revised the manuscript.

\section{Acknowledgments}

We thank Michelle Campbell, Martin Barron, and Ralf Paus for the critical reading of the manuscript. This study was supported by the COST Action BM1007 "Mast cells and Basophils: targets for innovative therapies."

16. Fox CC, Jewell SD, Whitacre CC. Rat peritoneal mast cells present antigen to a PPD-specific T cell line. Cell Immunol (1994) 158:253-64. doi:10.1006/cimm. 1994.1272

17. Poncet P, Arock M, David B. MHC class II-dependent activation of CD4 ${ }^{+} \mathrm{T}$ cell hybridomas by human mast cells through superantigen presentation. J Leukoc Biol (1999) 66:105-12.

18. Suurmond J, van Heemst J, van Heiningen J, Dorjée AL, Schilham MW, van der Beek FB, et al. Communication between human mast cells and $\mathrm{CD} 4^{+} \mathrm{T}$ cells through antigen-dependent interactions. Eur J Immunol (2013) 43:1758-68. doi:10.1002/eji.201243058

19. Frandji P, Tkaczyk C, Oskéritzian C, Lapeyre J, Peronet R, David B, et al. Presentation of soluble antigens by mast cells: upregulation by interleukin-4 and granulocyte/macrophage colony-stimulating factor and downregulation by interferon-gamma. Cell Immunol (1995) 163:37-46. doi:10.1006/cimm.1995. 1096

20. Frandji P, Tkaczyk C, Oskeritzian C, David B, Desaymard C, Mecheri S. Exogenous and endogenous antigens are differentially presented by mast cells to CD4 T lymphocytes. Eur J Immunol (1996) 26:2517-28. doi:10.1002/eji.1830261036

21. Tkaczyk C, Villa I, Peronet R, David B, Mecheri S. FceRI-mediated antigen endocytosis turns interferon-gamma-treated mouse mast cells from inefficient into potent antigen-presenting cells. Immunology (1999) 97:333-40. doi:10. 1046/j.1365-2567.1999.00789.x

22. Gaudenzio N, Espagnolle N, Mars LT, Liblau R, Valitutti S, Espinosa E. Cell-cell cooperation at the T helper cell/mast cell immunological synapse. Blood (2009) 114:4979-88. doi:10.1182/blood-2009-02-202648

23. Gaudenzio N, Laurent C, Valitutti S, Espinosa E. Human mast cells drive memory $\mathrm{CD}^{+} \mathrm{T}$ cells toward an inflammatory IL-22+ phenotype. J Allergy Clin Immunol (2013) 131:1400-7. doi:10.1016/j.jaci.2013.01.029

24. Kambayashi T, Allenspach EJ, Chang JT, Zou T, Shoag JE, Reiner SL, et al. Inducible MHC class II expression by mast cells supports effector and regulatory T cell activation. J Immunol (2009) 182:4686-95. doi:10.4049/jimmunol. 0803180

25. Nakae S, Suto H, Iikura M, Kakurai M, Sedgwick JD, Tsai M, et al. Mast cells enhance $\mathrm{T}$ cell activation: importance of mast cell costimulatory molecules and secreted TNF. J Immunol (2006) 176:2238-48. doi:10.4049/jimmunol.176. 4.2238

26. Nakano N, Nishiyama C, Yagita H, Koyanagi A, Akiba H, Chiba S, et al. Notch signaling confers antigen-presenting cell functions on mast cells. J Allergy Clin Immunol (2009) 123:74-81. doi:10.1016/j.jaci.2008.10.040

27. Fujita T, Kambe N, Uchiyama T, Hori T. Type I interferons attenuate T cell activating functions of human mast cells by decreasing TNF-alpha production and OX40 ligand expression while increasing IL-10 production. J Clin Immunol (2006) 26:512-8. doi:10.1007/s10875-006-9043-1

28. Gong J, Yang NS, Croft M, Weng IC, Sun L, Liu FT, et al. The antigen presentation function of bone marrow-derived mast cells is spatiotemporally restricted to a subset expressing high levels of cell surface FceRI and MHC II. BMC Immunol (2010) 11:34. doi:10.1186/1471-2172-11-34 
29. Raposo G, Tenza D, Mecheri S, Peronet R, Bonnerot C, Desaymard C. Accumulation of major histocompatibility complex class II molecules in mast cell secretory granules and their release upon degranulation. Mol Biol Cell (1997) 8:2631-45. doi:10.1091/mbc.8.12.2631

30. Skokos D, Le Panse S, Villa I, Rousselle JC, Peronet R, David B, et al. Mast cell-dependent $\mathrm{B}$ and $\mathrm{T}$ lymphocyte activation is mediated by the secretion of immunologically active exosomes. J Immunol (2001) 166:868-76. doi:10.4049/ jimmunol.166.2.868

31. McAlpine SM, Issekutz TB, Marshall JS. Virus stimulation of human mast cells results in the recruitment of CD56 + T cells by a mechanism dependent on CCR5 ligands. FASEB J (2012) 26:1280-9. doi:10.1096/fj.11-188979

32. Avirutnan P, Matangkasombut P. Unmasking the role of mast cells in dengue. Elife (2013) 30(2):e00767. doi:10.7554/eLife.00767

33. Liu B, Meng D, Wei T, Zhang S, Hu Y, Wang M. Apoptosis and proinflammatory cytokine response of mast cells induced by influenza A viruses. PLoS One (2014) 9(6):e100109. doi:10.1371/journal.pone.0100109

34. Ebert S, Becker M, Lemmermann NA, Büttner JK, Michel A, Taube C, et al. Mast cells expedite control of pulmonary murine cytomegalovirus infection by enhancing the recruitment of protective CD8 T cells to the lungs. PLoS Pathog (2014) 10(4):e1004100. doi:10.1371/journal.ppat.1004100

35. Al-Afif A, Alyazidi R, Oldford SA, Huang YY, King CA, Haidl ID, et al. Respiratory syncytial virus infection of primary human mast cells induces the selective production of type I interferons, CXCL10, and CCL4. J Allergy Clin Immunol (2015). doi:10.1016/j.jaci.2015.01.042

36. Sandig H, Bulfone-Paus S. TLR signaling in mast cells: common and unique features. Front Immunol (2012) 3:185. doi:10.3389/fimmu.2012.00185

37. Orinska Z, Bulanova E, Budagian V, Metz M, Maurer M, Bulfone-Paus S. TLR3induced activation of mast cells modulates $\mathrm{CD}^{+}$T-cell recruitment. Blood (2005) 106:978-87. doi:10.1182/blood-2004-07-2656

38. Becker M, Lemmermann NA, Ebert S, Baars P, Renzaho A, Podlech J, et al. Mast cells as rapid innate sensors of cytomegalovirus by TLR3/TRIF signaling-dependent and -independent mechanisms. Cell Mol Immunol (2015) 12:192-201. doi: $10.1038 / \mathrm{cmi} .2014 .73$

39. Ott VL, Cambier JC, Kappler J, Marrack P, Swanson BJ. Mast cell-dependent migration of effector $\mathrm{CD}^{+} \mathrm{T}$ cells through production of leukotriene B4. Nat Immunol (2003) 4:974-81. doi:10.1038/ni971

40. Malaviya R, Twesten NJ, Ross EA, Abraham SN, Pfeifer JD. Mast cells process bacterial Ags through a phagocytic route for class I MHC presentation to T cells. J Immunol (1996) 156:1490-6.

41. Bertolini M, Zilio F, Rossi A, Kleditzsch P, Emelianov VE, Gilhar A, et al. Abnormal interactions between perifollicular mast cells and CD8+ T-cells may contribute to the pathogenesis of alopecia areata. PLoS One (2014) 9(5):e94260. doi:10.1371/journal.pone.0094260

42. Stelekati E, Bahri R, D’Orlando O, Orinska Z, Mittrücker HW, Langenhaun $\mathrm{R}$, et al. Mast cell-mediated antigen presentation regulates CD8+ T cell effector functions. Immunity (2009) 31:665-76. doi:10.1016/j.immuni.2009. 08.022

43. Gregory GD, Robbie-Ryan M, Secor VH, Sabatino JJ Jr, Brown MA. Mast cells are required for optimal autoreactive $\mathrm{T}$ cell responses in a murine model of multiple sclerosis. Eur J Immunol (2005) 35:3478-86. doi:10.1002/eji. 200535271

44. Maurer M, Lopez Kostka S, Siebenhaar F, Moelle K, Metz M, Knop J, et al. Skin mast cells control T cell-dependent host defense in Leishmania major infections. FASEB J (2006) 20:2460-7. doi:10.1096/fj.06-5860com

45. Heuer JG, Zhang T, Zhao J, Ding C, Cramer M, Justen KL, et al. Adoptive transfer of in vitro-stimulated $\mathrm{CD} 4{ }^{+} \mathrm{CD} 25^{+}$regulatory $\mathrm{T}$ cells increases bacterial clearance and improves survival in polymicrobial sepsis. J Immunol (2005) 174:7141-6. doi:10.4049/jimmunol.174.11.7141
46. Lu LF, Lind EF, Gondek DC, Bennett KA, Gleeson MW, Pino-Lagos K, et al Mast cells are essential intermediaries in regulatory T-cell tolerance. Nature (2006) 442:997-1002. doi:10.1038/nature05010

47. Eller K, Wolf D, Huber JM, Metz M, Mayer G, McKenzie AN, et al. IL9 production by regulatory $\mathrm{T}$ cells recruits mast cells that are essential for regulatory T cell-induced immune suppression. J Immunol (2011) 186:83-91. doi:10.4049/jimmunol.1001183

48. Kashyap M, Thornton AM, Norton SK, Barnstein B, Macey M, Brenzovich J, et al. Cutting edge: CD4 T cell-mast cell interactions alter IgE receptor expression and signaling. J Immunol (2008) 180:2039-43. doi:10.4049/jimmunol.180. 4.2039

49. Piconese S, Gri G, Tripodo C, Musio S, Gorzanelli A, Frossi B, et al. Mast cells counteract regulatory T-cell suppression through interleukin-6 and OX40/OX40L axis toward Th17-cell differentiation. Blood (2009) 114:2639-48. doi:10.1182/blood-2009-05-220004

50. Forward NA, Furlong SJ, Yang Y, Lin TJ, Hoskin DW. Mast cells down-regulate $\mathrm{CD}^{+} \mathrm{CD} 25^{+} \mathrm{T}$ regulatory cell suppressor function via histamine $\mathrm{H} 1$ receptor interaction. J Immunol (2009) 183:3014-22. doi:10.4049/jimmunol.0802509

51. Frossi B, D'Incà F, Crivellato E, Sibilano R, Gri G, Mongillo M, et al. Singlecell dynamics of mast cell-CD4 ${ }^{+} \mathrm{CD} 25^{+}$regulatory T cell interactions. Eur J Immunol (2011) 41:1872-82. doi:10.1002/eji.201041300

52. Gri G, Piconese S, Frossi B, Manfroi V, Merluzzi S, Tripodo C, et al. CD4 ${ }^{+} \mathrm{CD} 25^{+}$ regulatory $\mathrm{T}$ cells suppress mast cell degranulation and allergic responses through OX40-OX40L interaction. Immunity (2008) 29:771-81. doi:10.1016/j. immuni.2008.08.018

53. Feyerabend TB, Weiser A, Tietz A, Stassen M, Harris N, Kopf M, et al. Cremediated cell ablation contests mast cell contribution in models of antibodyand T cell-mediated autoimmunity. Immunity (2011) 35:832-44. doi:10.1016/j. immuni.2011.09.015

54. Gutierrez DA, Fu W, Schonefeldt S, Feyerabend TB, Ortiz-Lopez A, Lampi Y, et al. Type 1 diabetes in NOD mice unaffected by mast cell deficiency. Diabetes (2014) 63:3827-34. doi:10.2337/db14-0372

55. Lilla JN, Chen CC, Mukai K, BenBarak MJ, Franco CB, Kalesnikoff J, et al. Reduced mast cell and basophil numbers and function in Cpa3-Cre; Mcl-1fl/fl mice. Blood (2011) 118:6930-8. doi:10.1182/blood-2011-03-343962

56. Reber LL, Marichal T, Galli SJ. New models for analyzing mast cell functions in vivo. Trends Immunol (2012) 33:613-25. doi:10.1016/j.it.2012.09.008

57. Schubert N, Dudeck J, Liu P, Karutz A, Speier S, Maurer M, et al. Mast cell promotion of T cell-driven antigen-induced arthritis despite being dispensable for antibody-induced arthritis in which T cells are bypassed. Arthritis Rheumatol (2015) 67:903-13. doi:10.1002/art.38996

58. Brown MA, Hatfield JK, Walker ME, Sayed BA. A game of kit and mouse: the Kit is still in the bag. Immunity (2012) 36:891-2; author reply 893-4. doi:10. 1016/j.immuni.2012.05.004

59. Brown MA, Hatfield JK. Mast cells are important modifiers of autoimmune disease: with so much evidence, why is there still controversy? Front Immunol (2012) 3:147. doi:10.3389/fimmu.2012.00147

Conflict of Interest Statement: The authors declare that the research was conducted in the absence of any commercial or financial relationships that could be construed as a potential conflict of interest.

Copyright (C) 2015 Bulfone-Paus and Bahri. This is an open-access article distributed under the terms of the Creative Commons Attribution License (CC BY). The use, distribution or reproduction in other forums is permitted, provided the original author(s) or licensor are credited and that the original publication in this journal is cited, in accordance with accepted academic practice. No use, distribution or reproduction is permitted which does not comply with these terms. 